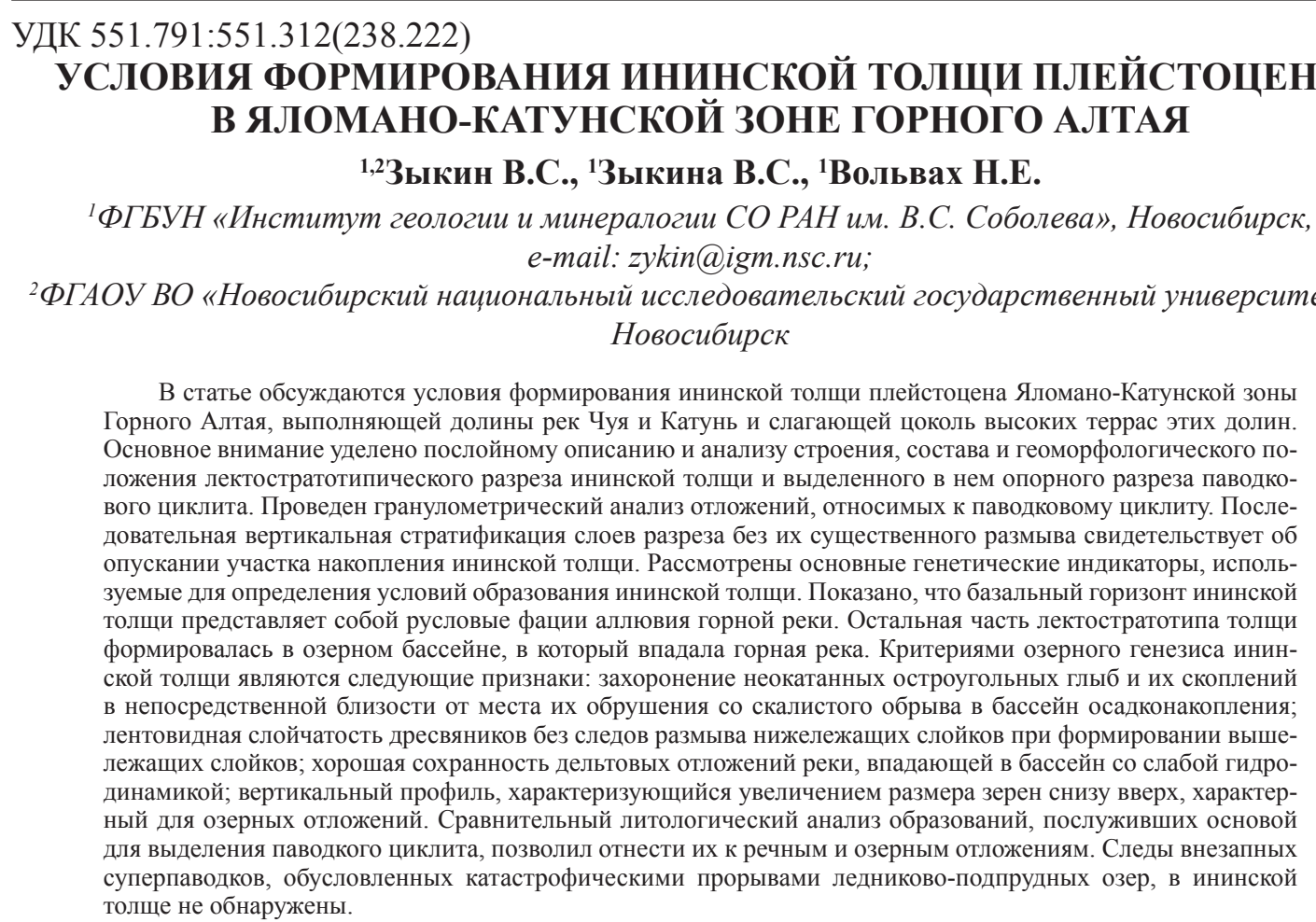

Ключевые слова: плейстоцен, речные, озерные отложения, катастрофические суперпаводки, Горный Алтай

\title{
CONDITIONS OF THE PLEISTOCENE INYA SERIES FORMATION YALOMAN-KATUN AREA OF THE ALTAI MOUNTAINS \\ 1,2Zykin V.S., ${ }^{1}$ Zykina V.S., ${ }^{1}$ Volvakh N.E.
}

${ }^{1}$ Sobolev Institute of Geology and Mineralogy SB of the RAS, Novosibirsk, e-mail: zykin@igm.nsc.ru; ${ }^{2}$ National Research Novosibirsk State University, Novosibirsk

\begin{abstract}
The paper presents conditions of the Inya series formation of Yaloman-Katun area of the Altai Mountains that takes up Katun and Chuya river valleys and forms high terraces basement there. Main attention is devoted to layer-by-layer description and to evaluation of structure, constitution and geomorphologic location of stratotype of Inya series and the reference section of the flood cyclite separated in it. Grain size measurements of flood cyclite deposits were realized. Successive vertical stratification of the section layers without its significant erosion suggests of putting down of the Inya series deposition area. The main genetic indicators using for determination of the Inya series formation condition are taken into consideration. Basic horizon is presented to be channel facies of mountain river alluvium. The rest of stratotype is formed in lake basin in which a mountain river flowed. Criterions of lacustrine genesis of the Inya series are next indications: burying of coarse angular blocks and its accumulation across the road from area of its rockfall in the basin when underlying layers formed; good preservation of river delta deposits flowing in the basin with weak hydrodynamic; vertical profile being described by increasing of grain size up-section is specific for lake deposits. Benchmarking lithological study of deposits provided a basis for separating flood cyclite allows to refer it to the river and lacustrine deposits. The evidences of sudden superflooding been responsible for catastrophic debacle of ice-dammed lakes in the the Inya series are not detected.
\end{abstract}

Keywords: Pleistocene, river, lake deposits, catastrophic superflooding, Altai Mountains

К ининской свите относятся мощные рыхлые терригенные отложения плейстоцена, залегающие в долинах рек Катуни и Чуи Горного Алтая и составляющие основной объем выполняющих их четвертичных образований. Они слагают цоколь высоких террас этих рек. В качестве самостоятельного стратиграфического подразделения они были установлены Н.А. Ефимцевым [1]. Со времени ее выделения представления об ус- ловиях формирования ининской толщи кардинально менялись. Н.А. Ефимцев считал, что эта толща представляет горный аллювий, в формировании которого участвовали отложения неглубоких проточных озер. По мнению Б.М. Богачкина, высказанному в 1981 г., вся ининская толща представлена комплексом ледниковых образований эпохи максимального оледенения, а высокие террасы представляют ледниково-аккумуля- 
тивные формы. В 1999 г. С.В. Парначев [2] отнес ининскую толщу к отложениям катастрофических паводков, выделив разрез первой пачки свиты в 250-300 м ниже устья p. Иня в качестве опорного разреза паводкового циклита. Во многих последующих работах [3-5] формирование ининской толщи связывается с прохождением в плейстоцене по долинам рек Чуя и Катунь внезапных, гляциально обусловленных суперпаводков. Новые данные, полученные авторами статьи в последнее время [6], противоречат гипотезе образования ининской толщи в результате деятельности катастрофических суперпаводков. Наличие альтернативных взглядов на условия формирования ининской толщи плейстоцена в этих долинах привело к необходимости послойного изучения геологических разрезов, послуживших основанием для обоснования различных точек зрения на ее генезис. Целью статьи является установление условий формирования ининской толщи плейстоцена, выполняющей долины рек Чуя и Катунь и выявление диагностических особенностей ее образования. Материалом послужили данные, полученные в результате проводимых с 2001 г. исследований строения, состава и геоморфологического положения рыхлых четвертичных отложений, выполняющих долины рек Чуя и Катунь в Яломано-Катунской зоне, а также морфологических особенностей обломочного материала и условий его залегания в этих долинах. Основное внимание уделяется изучению основного опорного разреза ининской толщи, предложенного в качестве ее лектостратотипического разреза [3], в котором находится опорный разрез паводкого циклита [2]. Основными методами являются литолого-генетический, гранулометрический методы и текстурный анализ. При конвергентном сходстве большинства текстур, формировавшихся в различных фациальных обстановках горных бассейнов осадконакопления, основной упор сделан на выявление признаков однозначно свидетельствующих о генезисе отложений.

\section{Строение и условия формирования ининской толщи}

Рыхлые отложения, слагающие высокие террасы рек Чуи и Катуни в Яломано-Катунской зоне, выделены Н.А. Ефимцевым [1] в ининскую толщу без обозначения стратотипа. Он указал, что наибольшим развитием и разнообразием ининская толща обладает в долине Катуни между устьями рек Чуи и Большого Ильгуменя. Из всех приведенных им разрезов наиболее представительным является разрез 180-метровой террасы, расположенный в правом борту долины р. Катунь, ниже по течению реки от устья р. Иня до скальных выходов г. Хрустальной протяженностью 700 м. Его наиболее обнаженная часть находится в овраге, тальвег которого расположен в 700 м ниже устья р. Иня, а отдельные фрагменты нижней части разреза обнажаются в уступе высокой террасы в интервале 500-700 м от устья р. Иня. В интервале от устья р. Иня до 500 м ниже его к 180-метровой террасе со стороны р. Катунь причленяется 55-метровая терраса (рис. 1, 2), закрывая низы разреза 180-метровой террасы. Изучение этого разреза имеет достаточно длительную и запутанную историю. Впервые этот разрез был схематично описан Н.А. Ефимцевым [1], позже Б.М. Богачкин в 1981 г. при описании этого разреза в обрыве 55-метровой террасы выделил в нем катунскую и яломанскую фации ининской толщи. Б.А. Борисов в 1987 г., приняв 180-метровую террасу за вал береговой морены, в разрезе, причленяющейся к ней 55-метровой террасы, 0,3 м ниже устья р. Иня выделил снизу вверх инегеньскую аллювиальную толщу, устьчуйскую морену, устьининскую, преимущественно аллювиальную толщу, куюсскую морену, эштыккольскую морену и перекрывающие их среднечетвертичные аллювиальные отложения. Из них три толщи являлись голостратотипами для трех нижнечетвертичных подгоризонтов - устьчуйского, устьининского и куюсского.

В 1999 г. С.В. Парначев [2] описал разрез 180-м террасы (преимущественно в овраге). Он расчленил его на семь пачек, каждая из которых, по его мнению, интерпретируется как след отдельного паводкового события, связанного с катастрофическим спуском высокогорных четвертичных ледниковоподпрудных водоемов. Разрез первой пачки ининской толщи мощностью 30 м был принят за опорный разрез паводкового циклита, в котором выделены селевая фация мощностью до 8 м, пойменная фация мощностью 22 м и фация самоотмостки толщиной 2 м. В своей публикации [2] он привел неточную привязку разреза, указав, что толща 180-метровой террасы вскрывается в правом борту долины р. Катунь, в 250-300 м ниже устья р. Иня. Позже И.Д. Зольников [3, 4], приведя в своих работах описание разреза С.В. Парначева [2], предложил его в качестве лектостратотипа ининской толщи. Не заметив, что описанные разными авторами разрезы относятся к разным геоморфо- 
логическим уровням, он посчитал [3, 4], что только описания С.В. Парначева «адекватно» отражают строение разреза, а представления Б.А. Борисова, опубликованные в 1987 г., являются неверными. Сложное сочленение элементов разреза различных геоморфологических уровней привело к совмещению разновозрастных частей разреза, искажению его строения и выделению достаточно мощных селевых фаций паводкового циклита. Инегеньскую аллювиальную толщу, устьчуйскую морену, устьининскую, преимущественно аллювиальную толщу, куюсскую морену, эштыккольскую морену и перекрывающие их среднечетвертичные речные отложения, описанные Б.А. Борисовым в 1987 г., И.А. Зольников [3, 4] отнес к ининской толще. Разнообразие мнений о строении разреза вызвало необходимость его тщательного изучения и прослеживания границ разновозрастных геологических тел.

Ининская толща, сложенная в ЯломаноКатунской зоне преимущественно темно-серыми параллельно слоистыми дресвяниками со слоями и линзами темно-серых неравномерно окатанных галечников, трансгрессивно заполняющих долины боковых притоков долины р. Катунь - рек Иня, Малый и Большой Яломан и более мелких долин более чем на 4 км от их устья. Дресвяники состоят из чередования субпараллельных протяженных плоских слойков, толщиной от 1 до $20 \mathrm{~cm}$, нижний из которых сложен более мелкозернистым материалом (с различным содержанием песка, гравия или дресвы), верх- ний - более крупнозернистым материалом, также с разным сочетанием мелкого щебня и мелкой гальки. Часто они наклонены к осевой части долины Катуни под углом 20-30. В каждой из нижних пачек ининской свиты происходит отчетливое увеличение размеров обломков снизу вверх по разрезу.

Наиболее полный разрез ининской толщи находится в обрыве правого склона долины р. Катунь в уступе 180-м террасы (рис. 1,2). Его наиболее обнаженный участок расположен в левом борту оврага, тальвег которого находится в 700 м ниже устья р. Иня. Овраг проходит почти перпендикулярно современному руслу р. Катунь, в месте причленения 180-метровой террасы к метаморфическим сланцам г. Хрустальной. Правый борт оврага сложен сланцами, левый борт - ининской толщей. К бровке разреза поверхность террасы снижена на 10,3 м от ее максимальной высоты. Уровень р. Катунь у устья р. Иня 701,6 м. В средней части левого борта оврага сверху вниз обнажаются следующие слои.

1. Неравномерное параллельное субгоризонтальное переслаивание плохо сортированных, преимущественно грубозернистых песков и разнозернистого, плохо сортированного, различно окатанного гравия с мелкой галькой до 3 см. Толщина слойков песка от 2 до $10 \mathrm{~cm}$, редко до $20 \mathrm{~cm}$, гравия до 3-5 см. Количество слойков гравия и их толщина увеличивается к кровле слоя. Нижняя граница отчетливая. Мощность 3,8 м.

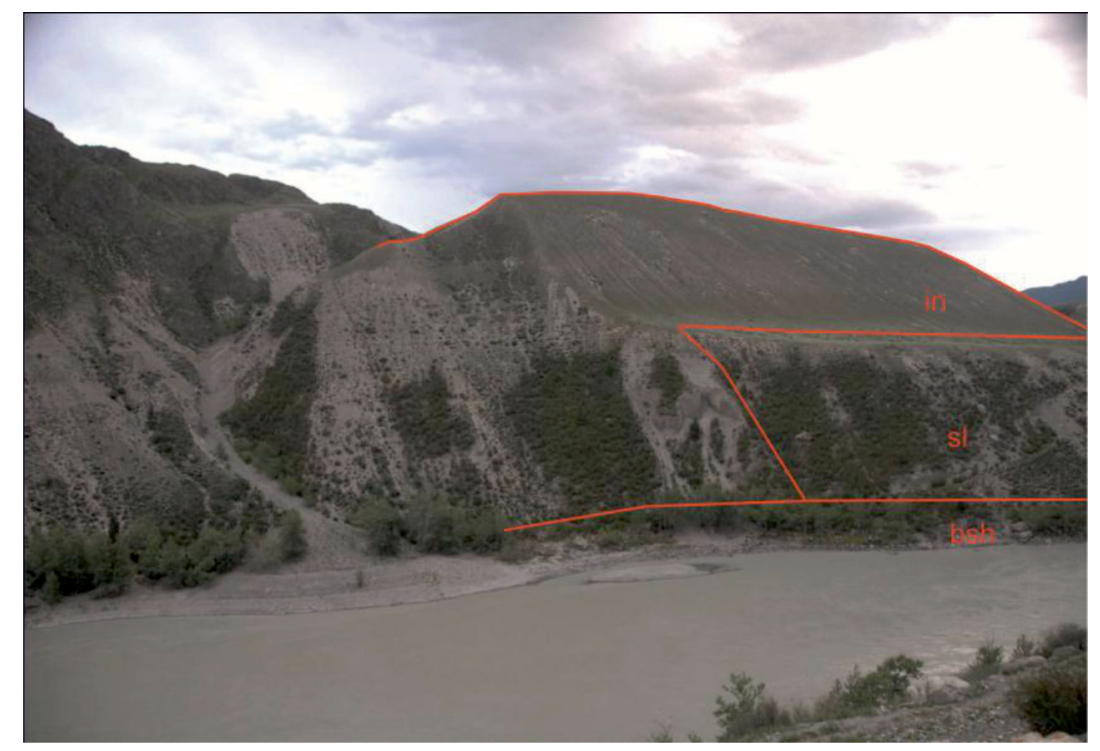

Рис. 1. Сочленение 180-м и 55-м террас в обрыве правого склона долины р. Катунь в интервале 100-700 м от устья p. Иня. bsh-башкаусская свита, іп-ининская свита, sl-cальджарская свита 


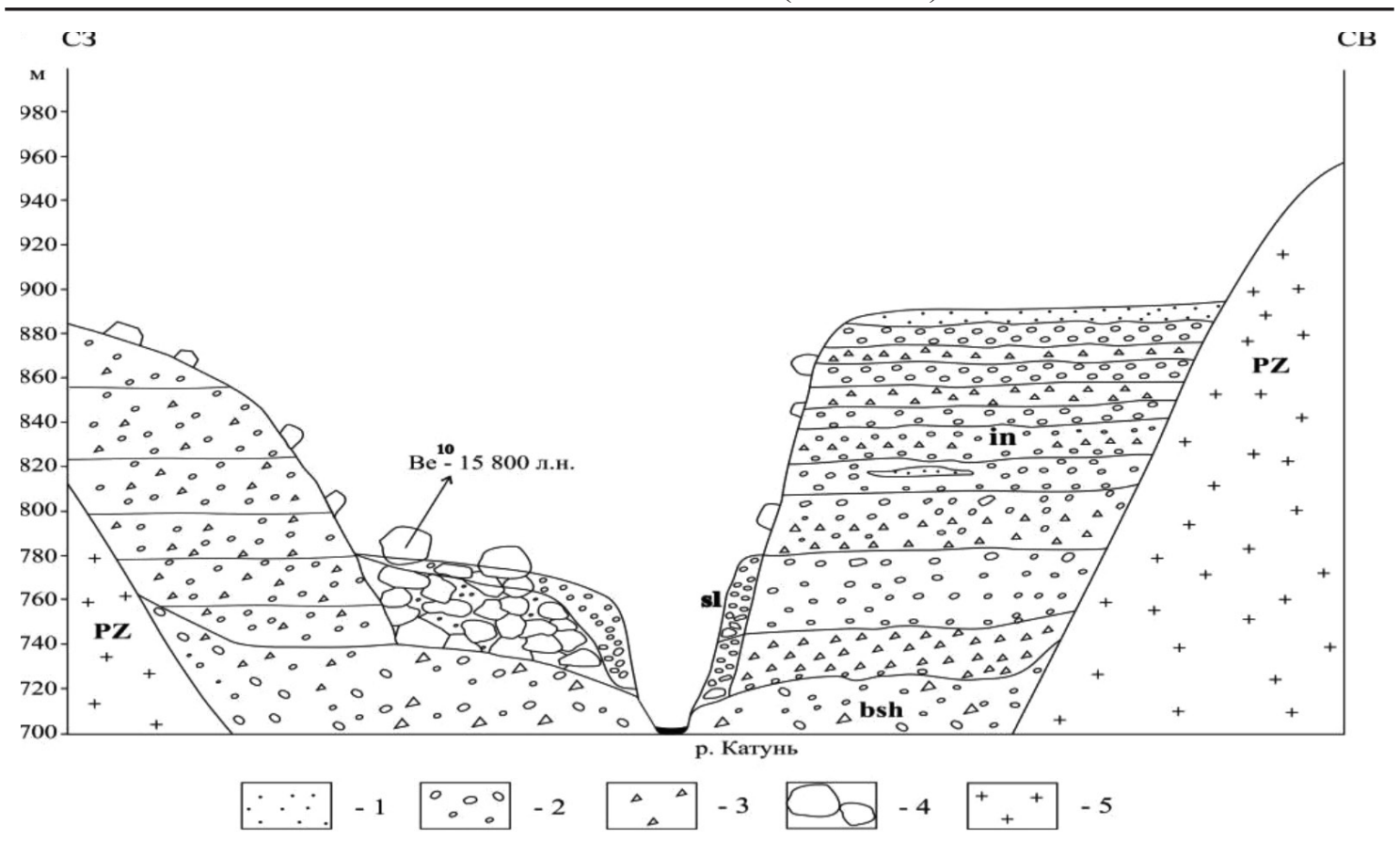

Рис. 2. Геологический разрез поперек долинь р. Катунь, 500 м ниже устья р. Иня. Горизонтальный масштаб 1:25000. 1 -песок, 2 - галька, 3 -дресва, 4 - глыбы, 5 - палеозой, bsh-башкаусская свита, іn-ининская свита, sl-сальджарская свита, PZ-палеозойские отложения

2. Галечник преимущественно из хорошо окатанных сланцев и известняков, часто встречаются умеренно и слабо окатанные гальки, редко присутствуют неокатанные обломки пород. Пространство между гальками заполнено разнозернистыми песками и гравием. Преобладает мелкая галька от 1 до $3 \mathrm{~cm}$, много гальки от 3 до $6 \mathrm{cm,} \mathrm{редко}$ до 8 см. Длинные оси плоских галек лежат субгоризонтально. Слойчатость неравномерная, линзовидная, с чередованием линз толщиной от 0,1 до 0,6 м с преобладанием галек разной размерности. Присутствуют линзы грубого гравия до 0,1 м. Нижняя граница отчетливая. Мощность 7,2 м.

3. Неравномерное субгоризонтальное переслаивание слойков дресвы различной размерности толщиной от 0,3 до $0,6 \mathrm{M}$, со слойками до 0,1 м грубозернистого плохо окатанного, плохо сортированного песка с большим количеством мелкой дресвы. Слойки дресвы содержат большое количество плохо окатанного песка и умеренно окатанной мелкой гальки до 2 см. Мощность $3,4 \mathrm{M}$.

4. Галечник хорошо промытый, преимущественно мелкий до $3 \mathrm{~cm}$, умеренно и слабо окатанный, с неотчетливой линзовидной слойчатостью. Много дресвы, гравия и мелкого щебня. Присутствуют упло- щенные гальки. С глубины 5 м от кровли слоя встречается хорошо окатанная галька до 4-6 см в поперечнике. В основании горизонт толщиной 0,5 м плохо сортированного гравия с большим количеством мелкой средне и плохо окатанной гальки, щебня и дресвы. Нижняя граница резкая неровная, слабо наклоненная в сторону современной реки. Мощность 10,8 м.

5. Дресвяник преимущественно косослойчатый, с толщиной косых серий до 3,5 м. Слойчатость обусловлена чередованием слойков от 1 до 5 см толщины, разнозернистых плохо сортированных, слабо окатанных песков, дресвяников, состоящих из уплощенных обломков сланцев, и мелкой различно окатанной плоской гальки сланцев. В нижней части встречаются неравномерно расположенные линзы до 0,6 м толщины, плохо сортированного дресвяника, обогащенного значительным количеством крупной, средней и мелкой гальки и редкими валунами до 15 см в поперечнике с мелкой субгоризонтальной и линзовидной слойчатостью до $2-3 \mathrm{~cm}$, редко до 10 см толщины со слойками мелкой гальки. Иногда присутствуют протяженные линзы толщиной до 0,5 м преимущественно хорошо окатанной и промытой крупной гальки. Размеры гальки по слою уменьшаются сни- 
зу вверх. Слой выполняет руслообразный врез. Нижняя граница резкая, неровная, наклонена вверх по оврагу. Мощность вверх по оврагу возрастает с 3,7 до 7,1 м,

6. Галечник плохо сортированный, средний, в основном хорошо и умеренно окатанный. Состоит из гальки известняков, гранитов, кварца, туфобрекчий и темноцветных сланцев. Много крупной и мелкой гальки, мелкого щебня. В нижней части преобладает мелкая галька. Пространство между гальками заполнено дресвой, мелким щебнем, галькой и гравием. К нижней части слоя содержание дресвы и мелкого щебня сланцев увеличивается. Слойчатость неравномерная, линзовидная, слабо наклонена вверх по оврагу, обусловлена чередованием линз толщиной до 0,4 м, различающихся по преобладанию галек различной размерности, а также заполнению межгалечникового пространства. В основании залегают линзы толщиной до 0,5 м крупной, хорошо окатанной гальки. Нижняя граница, неровная. Мощность 5,7 м.

7. Неравномерное переслаивание слойков дресвы и мелкой гальки с толщиной от 1 до 6 см. Они образуют субгоризонтально залегающие или очень слабо наклонные вверх по оврагу серии толщиной до 2,5 м. Слойки дресвы плотные, плохо сортированные, состоят обычно из уплощенных и вытянутых обломков сланцев до 5 мм, в них встречается много щебня и разнозернистого песка из зерен сланцев. Материал в слойках гальки плохо сортирован, обычно плохо и умеренно окатан. В слойках гальки и дресвы много плоского мелкого щебня. В основании залегают коричневато-серые, преимущественно грубозернистые, плохо сортированные пески с мелкой дресвой, гравием, редко мелкой галькой толщиной до 1 м, с параллельной, слабо наклоненной вниз по оврагу слойчатостью, с толщиной слойков до 1 см. Нижняя граница отчетливая, слабо наклонена вниз по оврагу. Мощность 14,7 м.

8. Галечник различно окатанный, плохо сортированный, преимущественно мелкий, с большим количеством средней, реже крупной гальки. Много щебня, дресвы и разнозернистых песков. Слойчатость крупная, линзовидная, неравномерная, с толщиной линз от 0,1 до 1,5 м. В линзах толщиной до 0,1 м много мелкой, преимущественно хорошо окатанной гальки, встречается крупная и средняя галька обычно хорошо окатанная, щебень и дресва сланцев. Более крупные линзы состоят в основном из грубого гравия с большим количеством дресвы и мелкого щебня сланцев, также мелкой и средней гальки. В интервале 0,5-2 м от кровли слоя расположена линза, выполняющая руслообразную ложбину, протяженностью 24 м, с плоской верхней границей и резко выгнутой нижней. Она сложена серыми, плохо сортированными, среднезернистыми, местами слабо слюдистыми песками, с частыми неравномерно расположенными линзами плохо сортированного гравия толщиной 0,1-0,3 м. Пески имеют неправильную мелкую и среднюю линзовидную слойчатость толщиной до 3 см. Нижняя граница резкая, наклонена вниз по оврагу. Мощность 8,4 м.

9. Неравномерное параллельное переслаивание слойков дресвяников и мелких галечников, образующих пары слойков. Дресвяники плохо сортированные, различно обогащенные мелким щебнем и разнозернистым песком. Галечники мелкие, преимущественно плохо окатанные, с большим количеством щебня, с различным заполнением межгалечникового пространства дресвой. Много плоской гальки и щебня. В верхней части толщина слойков дресвяника от 1 до $6 \mathrm{~cm}$, и галечника от 2 до 10 см. С глубины 8 м толщина слойков мелкой гальки уменышается до 5 см, а толщина слойков дресвы увеличивается до 20 см. От кровли слоя до глубины 9 м часто встречаются мелкие валуны и крупная галька. В интервале 9-14 м крупность гальки уменьшается, преобладает мелкий щебень. Присутствуют неравномерно расположенные линзы полимиктовых грубозернистых песков толщиной до 1 см. Часто в слойках галечника увеличивается количество щебня. В интервале 14-27 м количество крупной гальки и толщина ее линз увеличивается. Нижняя граница резкая, неровная. Мощность 27 м.

10. Галечник преимущественно хорошо окатанный, плохо сортированный с большим количеством щебня, дресвы и плохо сортированного разнозернистого песка. Галька состоит в основном из темных метаморфических сланцев, а также серых песчаников, темно-серых известняков, реже из серых гранитов и гранодиоритов. Ее размеры увеличиваются снизу вверх. Слойчатость крупная, линзовидная, неравномерная от 0,3 до 3,5 м толщины. Наклон слойков в линзах до 35 градусов. Встречаются линзы толщиной до 1 м, с отчетливой градацией галек от крупных в основании слоя до мелких в его верхней части. В верхней части в линзах преобладает крупный галечник с мелкими валунами. В нижней части - мелкий. Нижняя граница отчетливая, наклонена к осевой части долины Катуни под углом 30 градусов вдоль оврага. Мощность 30 м. 


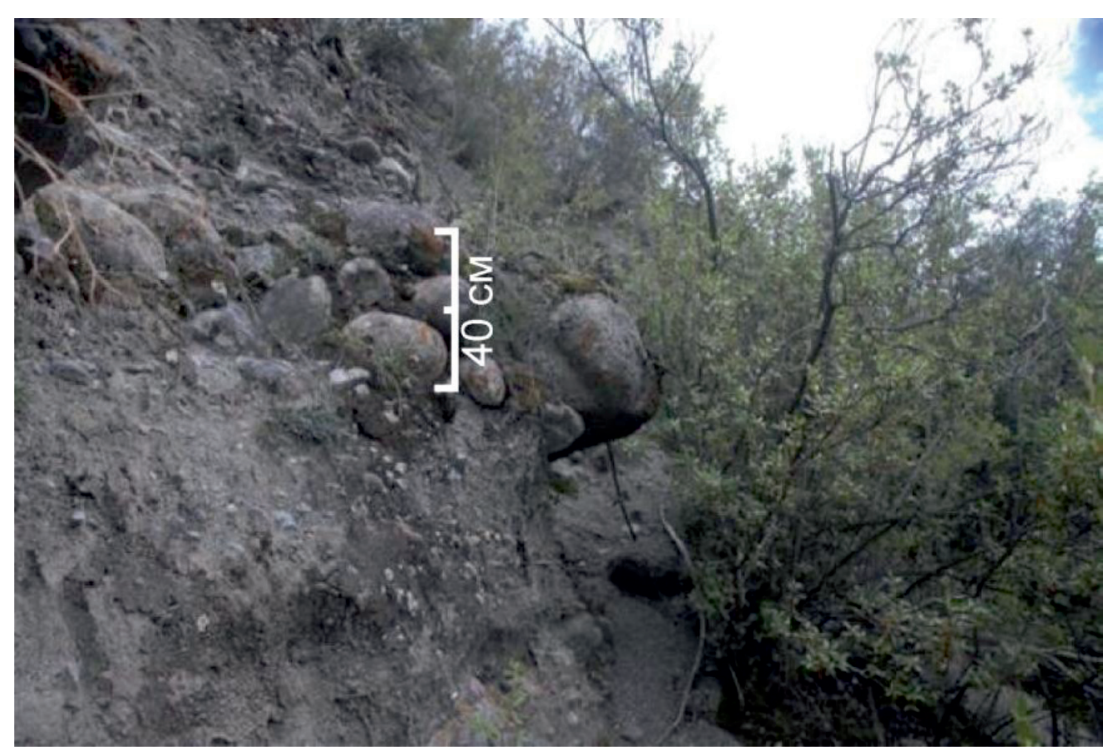

Рис. 3. Базальный слой ининской свиты в ее лектостратотипическом разрезе в правом борту долины р. Катуни, 550 м ниже по течению от устья р. Иня

11. Неравномерное переслаивание слойков мелкого дресвяника и мелкого щебня с большим количеством крупной дресвы и различно окатанной, мелкой, реже средней галькой. Снизу вверх увеличивается толщина слойков и размеры обломочного материала, их слагающего. Толщина слойков дресвы 2-5 см в нижней части и $10 \mathrm{~cm}$ в его верхней части, толщина слойков щебня 2-10 см в нижней части и до $20-30$ см в верхней части. Слойки образуют неотчетливые серии до 3 м толщины, наклоненные в сторону р. Катунь под углом 20 градусов. В интервале 5-8 м от кровли находится округлый ксенолит, состоящий из различно окатанных валунов до 0,2 м в поперечнике, заполнителем служит хорошо окатанная галька различных размеров. Нижняя граница отчетливая. Мощность 25 м.

12. Галечник серый, плохо сортированный, преимущественно хорошо окатанный. Размер гальки от 1 до 10 см. Встречаются хорошо окатанные валуны светло-серого гранита до 0,3 м в поперечнике (рис. 3). Заполнителем служит плохо сортированный, различно окатанный гравий, дресва метаморфических сланцев и серые, разнозернистые, слюдистые пески. Встречается щебень. Слойчатость неотчетливая, линзовидная, слабо наклонена вдоль современной реки. Нижняя граница резкая, неровная. Мощность 2,8 м.

Все слои разреза ининской толщи имеют темно-серый цвет. Материал представ- лен преимущественно различно окатанными обломками метаморфических сланцев. Почти во всех слоях разреза $(2,3,5,6,7,8$, 9) присутствуют неокатанные, часто остроугольные глыбы метаморфических сланцев, сложенные материалом г. Хрустальной от 0,4 до 1,5 м в поперечнике. В слое 10 они образуют небольшие скопления. Во всех слоях уплощенные гальки и обломки залегают преимущественно субгоризонтально. Ининская толща в разрезе залегает с резким, неравномерным размывом на башкаусской свите. В 350 м ниже устья р. Иня и 150 м выше тальвега оврага ее основание лежит на высоте 19,7 м от уреза воды в p. Катуни. В устье р. Иня оно уходит под урез воды в р. Катунь. Башкаусская свита здесь представлена светло-серыми, плохо сортированными гравием, дресвой, песком и алевритом с карбонатным цементом, местами с неотчетливой линзовидной и косой слойчатостью.

Ининская толща в лектостратотипическом разрезе мощностью 146 м состоит из ритмично построенных слоев. Размыв верхних частей ниже залегающих слоев разреза во время формирования выше залегающих слоев отсутствует или незначителен. Вложение или врезание выше залегающих слоев в ниже залегающие слои также отсутствует. Такой тип последовательной вертикальной стратификации слоев относится к бассейновому генетическому комплексу осадконакопления [7], который характерен 
для опускающихся участков или блоков земной коры. Существенной особенностью описанного разреза, в котором слагающие его осадки примыкают к скальному уступу г. Хрустальной, сложенному метаморфическими сланцами, является наличие совершенно неокатанных глыб и обломков различных размеров этих сланцев почти во всех слоях. Это свидетельствует о залегании и захоронении этих глыб и обломков вблизи их обрушения без удаления на большое расстояние и является признаком слабой гидродинамики водной среды в озерном водоеме, формирующей эти отложения и высокой скорости осадконакопления. Преобладание в ининской толще обломочного материала преимущественно однообразного петрографического состава, представленного в основном метаморфическими сланцами и темными известняками, также позволяет предполагать его незначительный перенос от источника сноса. Присутствие в разрезе большого количества плохо окатанного и совсем неокатанного материала (щебня и дресвы) свидетельствует о поступлении в бассейн большого количества рыхлого материала с ближайших горных склонов.

При описании разреза в нем установлено 12 мощных слоев, объединенных в 7 циклически построенных пачек. Верхние слои (1-6) образуют 3 циклита мощностью 11-14 м, включающие пары слоев, состоящие в нижней части в основном из мелкого или среднего различно окатанного галечника с неравномерной линзовидной слойчатостью. В верхней части они сложены параллельно слоистыми дресвяниками или песками, имеющими слабо наклонную или субгоризонтальную параллельную слойчатость ленточного типа, с чередованием слойков с более крупным и более мелким обломочным материалом. Параллельная слойчатость ленточного типа в слоях дресвяника и песка, находящихся в верхних частях верхних циклов, характерна для озерных осадков [8]. Присутствие в этих слоях неокатанных глыб метаморфических сланцев скального выступа г. Хрустальной в непосредственной близости от обрушения подтверждает их формирование в слабо подвижной водной среде озерного бассейна. Текстурные особенности слоев галечника с неравномерной линзовидной слойчатостью небольшой толщины в нижних частях верхних циклитов, их мощность и эрозионный характер нижних границ позволяют относить их к образованиям древней доли- ны р. Иня, впадающей в озерный бассейн. Нижележащий цикл, образованный слоями 7 и 8, резко увеличивается в мощности до 23,1 м. Наличие в слое 8 руслообразной песчаной линзы с неравномерной линзовидной слойчатостью толщиной до 1,5 м и протяженностью до 24 м позволяет отнести ее к дельтовым отложениям древней р. Ини. Увеличение зернистости вверх по разрезу в слое 7 позволяет предполагать его образование в озерном бассейне [8]. Слои 9, 10 и 11 образуют самостоятельные циклиты, в которых происходит увеличение крупности обломочного материала вверх по разрезу. В слое 9 к кровле слоя постепенно увеличивается размер галечного материала. В его верхней части встречаются мелкие валуны, отсутствующие в нижней и средних частях слоя. Наряду с наличием большого количества неокатанных обломков метаморфических сланцев г. Хрустальной эти данные свидетельствуют об озерной обстановке формирования этого слоя. В слоях 10 и 11 , образующих самостоятельные циклы осадконакопления, толщина линз и слойков, а также размер зерен кластического материала в них увеличиваются вверх по разрезу, что однозначно свидетельствует об их формировании в озерном бассейне [8]. Залегающий в основании ининской толщи базальный слой 12 (рис. 3), обнажающийся в Яломано-Катунской зоне в единственном разрезе, только в 550 м от устья р. Иня, имеет максимальную мощность 2,8 м. Его строение, состав, текстурные особенности и условия залегания позволяют относить его к стрежневым фациям горной реки. В остальных частях разреза он прикрыт отложениями 55-метровой террасы. Слои 11 , 12 и нижнюю часть слоя 10 описанного разреза С.В. Парначев [2] принял за опорный разрез паводкового циклита.

В приведенном описании разреза количество выделенных циклитов совпадает с числом пачек, выделенных С.В. Парначевым [2], но их внутреннее содержание и мощности, а также генетические особенности отличаются. Существенно уточнена мощность, положение и строение базального горизонта ининской толщи, послужившего С.В. Парначеву в качестве эталона селевой фации паводкового циклита. Максимальный размер валунов, находящихся в базальном горизонте, не превышает 0,3 м, тогда как С.В. Парначев [2] указывает на наличие в этом горизонте глыб, размер которых достигает 4 м. По-видимому, за крупные глыбы в базальном слое ининской тол- 
щи приняты глыбы, сползшие вниз по склону из размытых фрагментов 55-метровой террасы, сохранившихся над обнажением базального слоя. Также существенно отличается и мощность базального слоя ининской толщи - вместо 4-8 м у С.В. Парначева [2] их мощность составляет всего 2,8 м. Слой 11 , отнесенный им к пойменным фациям паводкого циклита, как показано выше, имеет отчетливые признаки озерных отложений. Таким образом, детальное изучение лектостратотипического разреза ининской толщи и опорного разреза паводкового циклита не выявило в нем следов гигантских катастрофических паводков. Большая часть разреза формировалась в озерном бассейне с участием дельтовых отложений р. Иня. Фациальногенетические особенности отложений, выделенные С.В. Парначевым [2] в паводковый циклит в его опорном разрезе, позволяют относить их к речным (селевые фации) и озерным (пойменные фации) отложениям.

Отчетливые признаки озерного происхождения низов ининской толщи выявлены в обрыве левого склона долины р. Иня в разрезе этой же 180 м террасы долины р. Катунь, находящегося 500 м вверх по ее течению от устья, ниже моста через реку, приблизительно 800 м южнее описанного выше разреза. На этом участке р. Иня прорезает высокую террасу Катуни, вскрывая низы ининской толщи до 38 м мощности. Разрез представлен параллельно-слоистыми темно-серыми дресвяниками с толщиной слойков от 1 до 30 см, залегающих друг на друге без видимых перерывов в осадконакоплении. Слойки дресвяников формируют пары, состоящие из повторяющихся слойков, с относительно более мелким и более крупным обломочным материалом. Эрозионных контактов между слойками не наблюдается. Толщина слойков мелкой дресвы составляет $1-5$ см в нижней части и 10 см в его верхней части, толщина слойков крупной дресвы и мелкого щебня - 2-10 см в нижней части и до 20-30 см в верхней части. На 6 уровнях этого разреза присутствуют линзы галечника длиной до 8 м и мощностью до 4,5 м. Они хорошо и умеренно окатаны, имеют неравномерную линзовидную слойчатость и слойчатость выполнения, резкую нижнюю границу и выполняют руслообразные врезы (рис. 4). В нижней части линз присутствуют мелкие валуны до 0,3 м в поперечнике. По текстурным особенностям, руслообразной форме линз галечника, их размерам и соотношению с вмещающими их отложениями они относятся к дельтовым образованиям небольшой горной реки, которую наследует современная р. Иня. Сохранность русловых отложений и соотношение с вмещающими линзы галечника породами показывает, что это речка впадала в достаточно крупный озерный бассейн. При впадении горной реки небольших размеров в быстро текущий поток суперпаводка переносимый ей материал не смог бы сформировать отчетливо обособленных отложений. Вблизи этого разреза из нижней части ининской толщи, на противоположном берегу р. Иня, в 10 м выше моста через реку получена OSL-дата $125,3 \pm 8,4$ тыс. лет [9], свидетельствующая об образовании ининской толщи в последнее межледниковье.

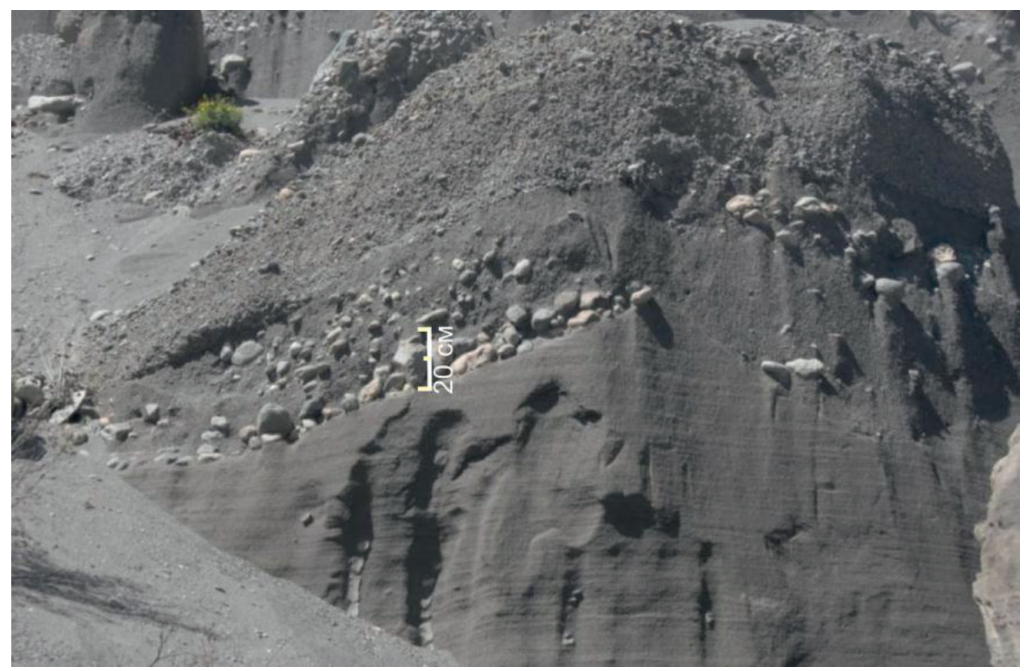

Рис. 4. Руслообразные врезы в основании линз галечников в параллельно-слоистых дресвяниках ининской толщи в разрезе левого борта долины р. Иня, 500 м выше устья 
Результаты гранулометрического анализа

Распределение размеров зерен обломочного материала по вертикальному профилю является важным признаком, для заключения об обстановках формирования осадков $[8,10]$. Для проведения гранулометрического анализа были отобраны точечным способом пробы из двух сечений вышеописанных разрезов ининской толщи. Это - слой 11 , принятый за опорный разрез паводкового циклита (58 образцов) и разрез одного из нижних циклитов ининской толщи, в 500 м от устья р. Иня (78 образцов). Так как отложения ининской толщи имеют ритмичную слойчатость с чередованием слойков, отличающихся по крупности обломочного материала смежных слойков, то для предотвращения ошибок отбирался двойной набор проб, т.е. пробы с относительно более крупным и мелким обломочным материалом. Опробование проводилось через каждый метр. Отобранные образцы подвергались предварительной механической дезинтеграции для предотвращения слипания обломков вследствие цементирования их глинистым материалом, содержащимся в пробе. Гранулометрический анализ проводился сухим методом (ситовой анализ) проб виброгрохотом «Analysette 3 » на наборе лабораторных сит марки «Analysette» с квадратными ячейками размером 0,$125 ; 0,25 ; 0,5 ; 1,2$ и 5 мм. Фракции взвешивались на лабораторных весах с точностью измерения 0,1 г. Результаты анализа записывались в виде таблицы измеренных масс каждой отдельной фракции частиц. Для каждой пробы вычислялась медианная крупность зерна. После измерения и расчета всех проб строились графики распределения медианного размера зерен и распределение процентного соотношения содержания гранулометрических фракций в образцах по разрезу (рис. 5).

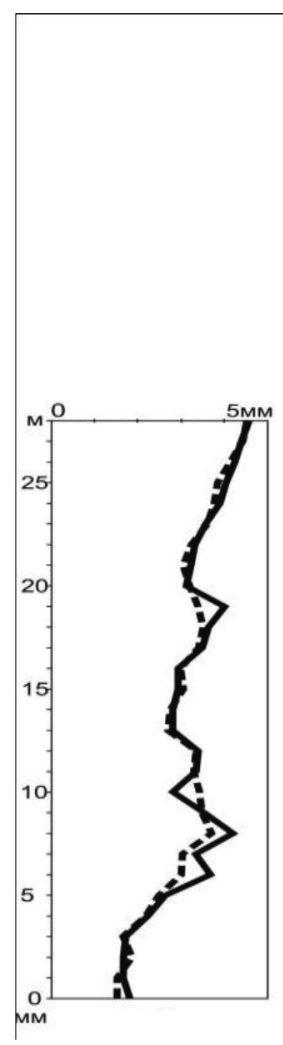

a)

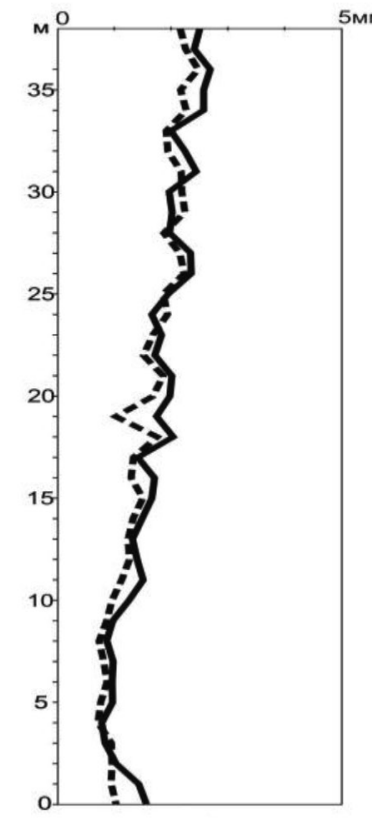

б)

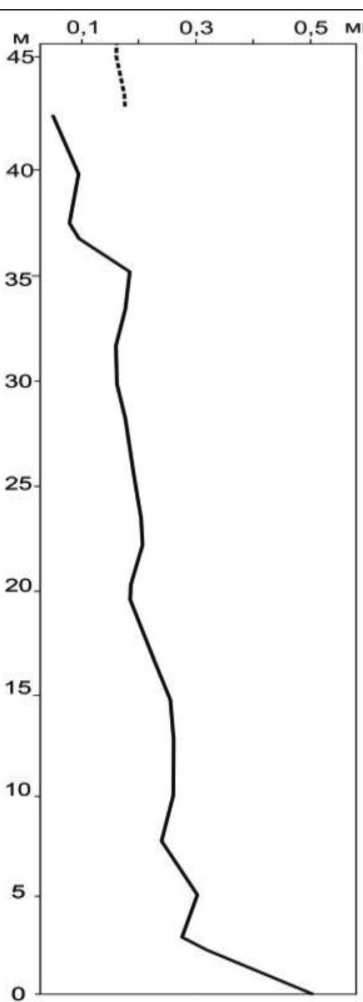

в)

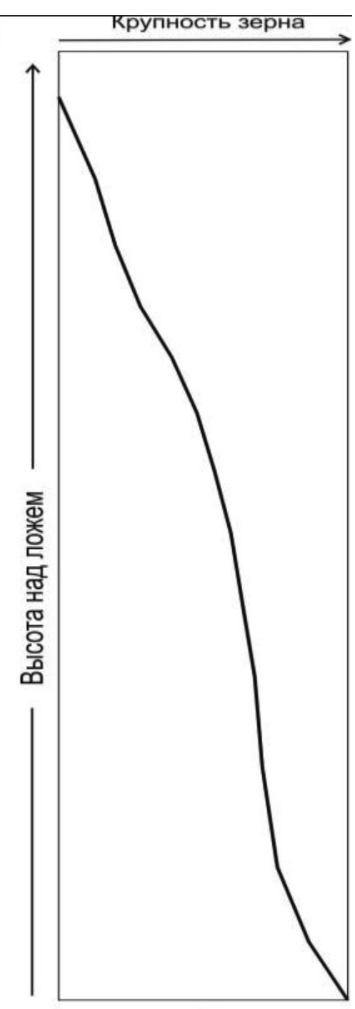

2)

Рис. 5. Сравнение кривых распределения размера зерен по вертикальному профилю различных отложений, a-распределение медианного размера зерен в слое 11 в разрезе правого борта долинь p. Катуни; $\sigma$-распределение медианного размера зерен в параллельно-слоистых дресвяниках ининской толщи в разрезе левого борта долины р. Иня; в-распределение медианного размера зерен русловых аллювиальных песчаников реки Иллинойс [8]; г - изменения размера частии в отложениях мутьевого потока [10] 
Гранулометрический анализ отложений разреза, находящегося на р. Иня, показал постепенное увеличение медианного размера обломочного материала по вертикальному профилю снизу вверх от 1,62 мм (1,04 мм для парной пробы) до 2,52 мм (2,14 мм) (рис. 5, б). Анализ отложений слоя 11, принятого за опорный разрез пойменной фации типового паводкового циклита [2] (рис. 5, а) продемонстрировал более резкое укрупнение снизу вверх медианного размера обломочного материала от 1,83 мм (1,59 мм) до 4,59 мм (4,50 мм) и постепенное преобладание крупных фракций над мелкими. Полученное распределение медианного размера обломков характерно для фаций озерных отложений, в которых идеальным разрезом является вертикальный профиль, в котором более тонкозернистые осадки сменяются более грубозернистыми береговыми образованиями [8].

Сравнительный анализ полученных вертикальных профилей циклитов ининской толщи с вертикальными литологическими моделями формирования потоковых отложений (аллювий - рис. 5, в, и мутьевой поток-рис. 5, г), близких по динамике среды с образованиями суперпаводков показал их значительные различия. Для медианного размера зерен (рис. 5, в) в вертикальном разрезе аллювия [8] характерно уменьшение медианного размера зерен вверх по разрезу, что связано с самой природой явления переноса материала потоком, так как при уменьшении несущей способности потока уменьшается и масса (размер) несомого материала. Другим типом образования градационного слоистого осадка являются мутьевые потоки, характерные для морских обстановок и крупных озер. Мутьевые потоки представляют собой особый тип плотностных течений, представляющих собой движение жидкости, обладающей большей плотностью относительно неподвижной жидкости с меньшей плотностью [10]. Они возникают на склоне дна при нарушении равновесия рыхлого осадка его. В потоках в виде суспензии несется обломочный материал различного размера и при падении скорости движении и несущей способности, из взвеси выпадают частицы в порядке уменьшения их массы. Соответственно, распределение обломков в вертикальном разрезе получается прямо градационным, т.е. от крупных к мелким. Сравнение распределения медианных размеров зерен по разрезу отложений мутьевого потока, аллювия и озерных образо- ваний позволяет полностью исключить из генезиса параллельно слоистых дресвяников ининской толщи потоковую составляющую, т.е. их происхождение за счет катастрофических паводков, мутьевых потоков или речной деятельности.

\section{Результаты исследования и их обсуждение}

K основным критериям отнесения ининской толщи, выполняющей долину Катуни, к образованиям гигантских катастрофических паводков, по мнению их сторонников [3, 4], относится наличие в них элементов паводкового циклита, выделенного С.В. Парначевым [2]. Наиболее характерными элементами этого циклита являются селевая и пойменная фации $[11,12]$, выделенные в разрезе ининской свиты. За опорный разрез паводкового циклита принят разрез нижней пачки ининской толщи в 180-метровой террасе правого борта долины Катунь, в 500 м ниже устья р. Иня.

Одним из генетических индикаторов гляциальных суперпаводков, по мнению И.Д. Зольникова и его соавторов, являются глыбовники [11, 12], достигающие мощности 8 м и протягивающиеся на сотни метров, а нередко и на километры вдоль осей магистральных долин. Последовательное прослеживание ининской толщи вдоль долин рек Катунь и Чуя и ее боковых притоков не выявило широкого распространения глыбовников, как залегающих в основании ининской толщи, так и внутри нее в основании отдельных циклитов. В опорном разрезе паводкого циклита лектостратотипического разреза ининской свиты, валунно-глыбовый горизонт типичной селевой фации, состоящий по представлениям С.В. Парначева [2] из глыб до 4 м в поперечнике и полуокатанного и плохо сортированного песчано-дресвяно-щебнистого материала и достигающего мощности 8 м, оказался по составу, строению, текстурным особенностям и условия залегания типичными отложениями горной реки (рис. 3). Его максимальная мощность достигает 2,8 м (см. выше).

Кроме лектостратотипа базальные слои ининской толщи вскрываются в другом известном разрезе в левом борту долины p. Катунь в основании 220-м террасы Катуни непосредственно ниже поселка Инегень [2]. Здесь темно-серые параллельнослойчатые озерные дресвяники, лежащие в основании ининской толщи мощностью 11,2 м залегают без грубозернистого ба- 
зального горизонта на хорошо промытых речных отложениях, сложенных серыми, хорошо промытыми слюдистыми песками видимой мощностью 5,8 м, с линзами хорошо окатанного галечника. Эти пески резко отличаются от песков, слагающих цоколь 180 м террасы ниже устья р. Иня, литологически они близки современному аллювию p. Катунь в районе пос. Инегень. Пески выполняют переуглубление долины, глубиной более 20 м. Эта толща образует самостоятельное стратиграфическое подразделение плейстоцена - аргутскую свиту. Ее единственный выход на поверхность ниже пос. Инегень следует считать ее стратотипическим разрезом. В основании вышележащих пачек ининской толщи этого разреза встречаются линзы, содержащие валунноглыбовый материал на высоте 14 и 38 м над урезом воды в Катуни. Глыбы достигают $1-1,5$ м, очень редко до 2 м в поперечнике. Они не окатаны, остроугольны, имеют открытые трещины кливажа и представлены метаморфическими сланцами, слагающими на данном участке левый борт долины Катуни. Их образование связано с обрушением скального уступа, подмываемого водой и захоронением вблизи этого места.

Среди четырех разрезов, указанных C.В. Парначевым [2], в которых вскрывается ининская толща, приводится разрез «160-метровой террасы» в левом борту долины Катуни в урочище Сок-Ярык. Проведенные инструментальные измерения показали, что на этом участке присутствует только 100-метровая терраса. В 1 км ниже устья руч. Сок-Ярык отложения, отнесенные к ининской толще, залегают на хорошо выраженной морене мощностью 65 м, описанной еще М.Б. Богачкиным в 1981 г. Доказательством ледникового генезиса этой толщи служит наличие в ней ледогранников и глыб до 15 м в поперечнике с открытыми трещинами кливажа, что исключает их перенос в водном потоке [13]. Залегающие с резким размывом на ледниковых отложениях толща серых, алевритистых, плохо сортированных, преимущественно мелких галечников с косой слойчатостью мощностью 30 м, относится к более молодым отложениям. Другие скопления глыбового материала в Яломано-Катунской зоне приурочены к более молодой сальджарской толще и принадлежат морене последнего сартанского оледенения [13]. В разрезе ининской толщи по р. Малый Яломан [2, 5] вскрывается только ее часть мощностью 70 м. Таким образом, во всех описанных разрезах ининской толщи, относимых к отложениям катастрофических суперпаводков [2, 3, 5], отсутствует характерный элемент паводкового циклита - селевая фация.

Одним из наиболее характерных элементов паводкового циклита по представлениям сторонников гляциальных суперпаводков [2-4] является так называемая пойменная фация, представленная параллельно-слоистыми «дресвяниками и щебнедресвяниками». Составляющие их обломки горных пород транспортируются во взвешенном состоянии и выпадают из движущейся толщи воды при резком падении скорости и несущей способности потока в эрозионной тени. Присутствие слоев мелких остроугольных обломков различных размеров с параллельной слоистостью («дресвяников и щебнедресвяников») в четвертичных отложениях долин рек Чуя и Катунь является $[11,12]$ «визитной карточкой суперпаводков». Широкое распространение дресвяников, состоящих преимущественно из плоских слабо окатанных обломков палеозойских сланцев, в рыхлых толщах различного возраста и генезиса долин Катуни и Чуи, обусловлено составом пород, слагающих их борта и днища, представленными палеозойскими сланцами. Дресвяники ининской толщи состоят из чередования субпараллельных протяженных плоских слойков, толщиной от 5 до 20 см, нижний из которых сложен более мелкозернистым материалом (с различным содержанием песка, гравия или дресвы), верхний - более крупнозернистым материалом, также с разным сочетанием мелкого щебня и мелкой гальки. Часто они наклонены к осевой части долины под углом 20-30. В каждой из нижних пачек ининской свиты происходит отчетливое увеличение размеров обломков снизу вверх по разрезу. В параллельно-слоистых дресвяниках снизу вверх по разрезу постепенно увеличивается толщина слойков и размер обломков в слойках. Как показано выше, подобная последовательность осадконакопления характерна для озерных осадков.

\section{Заключение}

Проведенные детальные исследования строения, состава, геоморфологического положения лектостратотипического разреза ининской толщи плейстоцена и выделяемого в нем опорного разреза паводкового циклита в долине р. Катунь, в Яломано-Катунской зоне Горного Алтая позволили установить условия их формирования. Последовательная вертикальная стратификация 
слоев разреза без их существенного размыва свидетельствует об опускании участка накопления ининской толщи. Базальный горизонт ининской толщи представляет собой русловые фации аллювия горной реки. Остальная часть лектостратотипа толщи формировалась в озерном бассейне, в который впадала горная река. Критериями озерного генезиса ининской толщи являются следующие признаки: захоронение неокатанных остроугольных глыб и их скоплений в непосредственной близости от места их обрушения со скалистого обрыва; лентовидная слойчатость дресвяников без следов размыва нижележащих слойков при формировании вышележащих слойков; хорошая сохранность дельтовых отложений реки впадающей в бассейн со слабой гидродинамикой; вертикальный профиль, с увеличением размера зерен снизу вверх, характерный для озерных отложений. В процессе исследований не удалось выявить характерного элемента паводкового циклита - селевой фации, другой специфический элемент паводкового циклита отнесен к озерным образованиям. Следы внезапных суперпаводков, обусловленных катастрофическими прорывами ледниково-подпрудных озер, в ининской толще не обнаружены.

Работа выполнена в рамках государственного задания (проект № 03302016-0017) и при финансовой поддержке Российского фонда фундаментальных исследований (гранты № 16-05-00371.

\section{Список литературы}

1. Ефимцев Н.А. О строении и происхождении антропогеновых отложений долин рек Чуи и Катуни в Горном Алтае / Н.А. Ефимцев // Бюллетень комиссии по изучению четвертичного периода. - 1964. - № 29. - С. 115-131.

2. Парначев С.В. Геология высоких алтайских террас (Яломано-Катунская зона) / С.В. Парначев. - Томск: Изд-во ИПФ ТПУ, 1999. - 137 с.

3. Зольников И.Д. Стратотипы четвертичных отложений Яломано-Катунской зоны Горного Алтая / И.Д. Зольников // Геология и геофизика. - 2008. - Т. 49, № 9. - С. 906-918.

4. Зольников И.Д. Четвертичные отложения и рельеф долин Чуи и Катуни / И.Д. Зольников, А.А. Мистрюков. Новосибирск: Изд-во Параллель, 2008. - 182 с.

5. Carling P.A., Martini P., Herget J., Borodavko P., Parnachov S. Megaflood sedimentary valley fill: Altai Mountains, Siberia // Megaflooding on Earth and Mars. UK: Cambridge University Press. 2009. P. 243-266.

6. Зыкин В.С. Дискуссионные проблемы и современное состояние стратиграфии и палеогеографии квартера Западной Сибири / В.С. Зыкин, В.С. Зыкина // Фундаментальные проблемы квартера: итоги изучения и основные направления дальнейших исследований. - М.: ГЕОС, 2017. - С. 146-148.

7. Несмеянов С.А. Генетические комплексы континентальных отложений / С.А. Несмеянов. - М.: ЗАО «Книга и бизнес», 2012. - 397 с.

8. Условия древнего осадконакопления и их распознавание / под ред. Дж. Ригби, У. Хемблина. - М.: Изд-во Мир, 1974. $-328 \mathrm{c}$
9. Baryshnikov G. Russian Altai in the Late Pleistocene and the Holocene: Geomorphological catastrophes and landscape rebound: Fieldtrip guide / G. Baryshnikov, A. Agatova, P. Carling, J. Herget, A. Panin, G. Fdamiec, R. Nepop. - Barnaul: Publishing House of Altai State University, 2015. - 137 p.

10. Седиментология / Р. Градзинский, А. Костецкая, А. Радомский, Р. Унруг. - М.: Недра, 1980. - 640 с.

11. Зольников И.Д. Геологическое строение и генезис высоких террас Чуи и среднего течения Катуни / И.Д. Зольников, Е.И. Деев, Д.В. Назаров, С.А. Котлер // Фундаментальные проблемы квартера: итоги изучения и основные направления дальнейших исследований. - Ростов н/Д.: Изд-во ЮНЦ РАН, 2013. - С. 226-228.

12. Генезис отложений высоких террас рек Чуя и Катунь / И.Д. Зольников [и др.] // Геология и минерально-сырьевые ресурсы Сибири. - 2014. - № 1 (17). - С. 30-40.

13. О скоплениях глыбового материала в долинах рек Чуя и Катунь и распространении последнего позднеплейстоценового оледенения на Горном Алтае / В.С. Зыкин [и др.] // Доклады РАН - 2016. - Т. 470, № 3. - C. 311-314. DOI: $10.7868 / \mathrm{S} 0869565216270244$

\section{References}

1. Efimcev N.A. O stroenii i proisxozhdenii antropogenovy`x otlozhenii dolin rek Chui i Katuni v Gornom Altae / N.A. Efimcev// Byulleten' komissii po izucheniyu chetvertichnogo perioda. - 1964. - № 29. - P. 115-131.

2. Parnachev S.V. Geologiya vy`sokix altajskix terras (Yalomano-Katunskaya zona) / S.V. Parnachev. - Tomsk: Izd-vo IPF TPU, 1999. - 137 p.

3. Zol'nikov I.D. Stratotipy' chetvertichny`x otlozhenij Yalomano-Katunskoj zony` Gornogo Altaya / I.D. Zol’nikov // Geologiya i geofizika. - 2008. - T. 49, № 9. - P. 906-918.

4. Zol`nikov I.D. Chetvertichny`e otlozheniya i rel’ef dolin Chui i Katuni / I.D. Zol’nikov, A.A. Mistryukov. - Novosibirsk: Izd-vo Parallel', 2008. - 182 p.

5. Carling P.A., Martini P., Herget J., Borodavko P., Parnachov S. Megaflood sedimentary valley fill: Altai Mountains, Siberia // Megaflooding on Earth and Mars. UK: Cambridge University Press. 2009. P. 243-266.

6. Zy`kin V.S. Diskussionny`e problemy` i sovremennoe sostoyanie stratigrafii i paleogeografii kvartera Zapadnoj Sibiri / V.S. Zy`kin, V.S. Zy`kina // Fundamental`ny`e problemy` kvartera: itogi izucheniya i osnovny'e napravleniya dal'nejshix issledovanij. - M.: GEOS, 2017. - P. 146-148.

7. Nesmeyanov S.A. Geneticheskie kompleksy' kontinental'ny'x otlozhenij / S.A. Nesmeyanov. - M.: ZAO «Kniga i biznes», 2012. -397 p.

8. Usloviya drevnego osadkonakopleniya i ix raspoznavanie / pod red. Dzh. Rigbi, U. Xemblina. - M.: Izd-vo Mir, 1974. -328 p.

9. Baryshnikov G. Russian Altai in the Late Pleistocene and the Holocene: Geomorphological catastrophes and landscape rebound: Fieldtrip guide / G. Baryshnikov, A. Agatova, P. Carling, J. Herget, A. Panin, G. Fdamiec, R. Nepop. - Barnaul: Publishing House of Altai State University, 2015. - 137 p.

10. Sedimentologiya / R. Gradzinskij, A. Kosteczkaya, A. Radomskij, R. Unrug. - M.: Nedra, 1980. - 640 p.

11. Zol’nikov I.D. Geologicheskoe stroenie i genezis vy`sokix terras Chui i srednego techeniya Katuni / I.D. Zol`nikov, E.I. Deev, D.V. Nazarov, S.A. Kotler // Fundamental'ny`e problemy` kvartera: itogi izucheniya i osnovny`e napravleniya dal'nejshix issledovanij. - Rostov n/D.: Izd-vo YuNCz RAN, 2013. - P. 226-228.

12. Genezis otlozhenij vy`sokix terras rek Chuya i Katun ' / I.D. Zol’nikov [i dr.] // Geologiya i mineral`no-sy`r`evy`e resursy` Sibiri. - 2014. - № 1 (17). - P. 30-40.

13. O skopleniyax gly`bovogo materiala $\mathrm{v}$ dolinax rek Chuya i Katun` i rasprostranenii poslednego pozdneplejstocenovogo oledeneniya na Gornom Altae / V.S. Zy`kin [i dr.] // Doklady' RAN - 2016. - T. 470, № 3. - P. 311-314. DOI: 10.7868/ S0869565216270244. 